\title{
Near-Road Exposure to Air Pollution and Allergic Rhinitis: A Cross-Sectional Study among Vendors in Dakar, Senegal
}

\author{
Fatou K. Sylla ${ }^{*}$, Adama Faye ${ }^{1}$, Mamadou Fall ${ }^{2}$, Masse Lo ${ }^{3}$, Aminata Diokhané4, \\ Nafissatou 0. Touré ${ }^{5}$, Anta TAL-DIA1
}

\author{
${ }^{1}$ Institute of Health and Development-Public Health and Preventive Medecine, Cheikh Anta Diop University (UCAD), Dakar, \\ Senegal \\ ${ }^{2}$ Laboratory of Toxicology and Hydrology, Cheikh Anta Diop University (UCAD), Dakar, Senegal \\ ${ }^{3}$ Institute of Leadership and Development (ILD), Dakar, Senegal \\ ${ }^{4}$ Air Quality Management Center of Dakar (CGQA), Dakar, Senegal \\ ${ }^{5}$ Pneumology Clinic CHU-Fann, Dakar, Senegal \\ Email: ^f.sylla@outlook.fr, adamafaye94@gmail.com, madoufal@gmail.com, masslo.massamba@gmail.com, \\ amimbow@gmail.com,nafioumar@gmail.com, adia@ised.sn
}

How to cite this paper: Sylla, F.K., Faye, A., Fall, M., Lo, M., Diokhané, A., Touré, N.O. and TAL-DIA, A. (2017) Near-Road Exposure to Air Pollution and Allergic Rhinitis: A Cross-Sectional Study among Vendors in Dakar, Senegal. Occupational Diseases and Environmental Medicine, 5, 106-120.

https://doi.org/10.4236/odem.2017.54010

Received: October 11, 2017

Accepted: November 6, 2017

Published: November 9, 2017

Copyright $\odot 2017$ by authors and Scientific Research Publishing Inc. This work is licensed under the Creative Commons Attribution International License (CC BY 4.0).

http://creativecommons.org/licenses/by/4.0/

\section{c) (i) Open Access}

\begin{abstract}
Introduction: The work environment is one of the main causes of allergic rhinitis. The majority of vendors in Dakar work in places close to roads that are very frequented by vehicles, exposing them to increased air pollution. The study determined the prevalence of allergic rhinitis and its associated risk factors in these vendors. Methods: This was a cross-sectional survey based on a structured questionnaire, conducted among vendors in the neighborhoods of HLM, Medina and Petersen in Dakar, Senegal. A total of 200 vendors were interviewed. Symptoms of allergic rhinitis were defined as the simultaneous presence of rhinorrhea, nasal congestion and sneezing in the absence of respiratory infection. A logistic regression analysis was performed to determine the relationship between socio-demographic characteristics, occupational factors, and allergic rhinitis. Results: Results of the study show a prevalence of $43 \%$ of allergic rhinitis among vendors. Multivariate analysis showed that the independent factors associated with allergic rhinitis in these vendors were age [OR: $3.28(1.02-10.51)$ ], working area [OR: $8.31(2.39-28.95)]$, exposure to multiple sources of pollution [OR: 4.08 (1.43 - 11.63)], and recurrent cold [OR: 4.39 (1.15 - 16.85)]. Conclusion: The prevalence of allergic rhinitis was high among vendors in Dakar. Our data suggest that exposure to air pollution at the workplace in vendors could lead to allergic rhinitis.
\end{abstract}




\section{Keywords}

Air Pollution, Traffic, Vendors, Allergic Rhinitis, Senegal

\section{Introduction}

Allergic rhinitis (AR) is a major health problem, affecting many people from childhood to adulthood [1]. It affects $20 \%-40 \%$ of the world's population, although the prevalence varies with age and region [2] [3]. Rhinitis is characterized by nasal symptoms such as sneezing, rhinorrhea, itching or nasal congestion due to inflammation of the nasal mucosa [4]. Considered a minor respiratory disease, allergic rhinitis is often ignored, underdiagnosed, misdiagnosed or mistreated [5] [6]. In addition to respiratory symptoms, allergic rhinitis is often accompanied by symptoms involving the eyes, throat, and ears [4] [5]. However, these symptoms can affect work performance, the quality of daily life and the use of medical care [7]. The causes of the increase in the prevalence of allergic rhinitis remain to be determined. A variety of risk factors including socio-economic status, exposure to tobacco smoke, air pollution, birth during the pollen season, exposure to allergens has been associated with allergic rhinitis [8] [9]. In sub-Saharan Africa, the International Study of Asthma and Allergies in Childhood (ISAAC) survey [10] showed the existence of allergic rhinitis with differences in prevalence between countries ranging from $7.5 \%$ in Ethiopia to $49 \%$ in Ivory Coast. This difference is also observed between urban and rural areas. Air pollution is suspected to be the cause of the increase in the prevalence of rhinitis in the urban areas. In the developing countries, air pollution from cars is the major contributor to urban air pollution. Road traffic generates pollutants such as nitrogen oxides $(\mathrm{NOx})$, sulfur dioxide $\left(\mathrm{SO}_{2}\right)$, ozone $\left(\mathrm{O}_{3}\right)$, particles having an aerodynamic diameter of $10 \mu \mathrm{m}$ or less $\left(\mathrm{PM}_{10}\right)$ and particles having an aerodynamic diameter of $2.5 \mu \mathrm{m}$ or less $\left(\mathrm{PM}_{2.5}\right)$ [11] [12]. These pollutants can induce oxidative stress and hyperreactivity of the airways. As a result, they increase allergic responses and inflammation of the respiratory tract [13] [14] [15]. Air pollution from cars is therefore a major risk factor for increasing the prevalence of allergic rhinitis. Globally, studies have shown associations between vehicle and industry emissions and an increased risk of allergic rhinitis [16] [17]. However, this association is not widely known in developing countries because the majority of epidemiological studies on air pollution from road traffic and allergic rhinitis are done in developed countries. In Senegal, a study carried out at the Pneumology Clinic in Dakar showed a prevalence of $8.2 \%$ of rhinitis, placing it in fourth place in all the pathologies seen in consultation [18]. Occupation is a known risk factor for allergic rhinitis [19]. In Africa, informal work accounts for more than $60 \%$ of urban employment. These workers in the informal sector do not receive any social protection for care [20]. They often spend long hours of work and confinement in cramped and unhealthy workplaces. Chronic respira- 
tory diseases are one of the most common diseases among workers in the informal sector [21]. Workers in the informal sector are more exposed to air pollution and its effects on respiratory health by their work environment than formal sector workers. Thus, vendors most often located near roads with high traffic, are highly exposed to air pollution. In Senegal, occupational respiratory allergies, although established, are characterized by a lack of knowledge of their prevalence. In Dakar, a study of workers in formal sector companies showed a prevalence of respiratory allergies in $14.2 \%$ of which $7.5 \%$ suffered from rhinitis [22]. The purpose of this study is to obtain data on respiratory health status like allergic rhinitis among vendors highly exposed to air pollution in Dakar in order to advocate and adopt targeted strategies to protect them on the harmful effects of traffic air pollution. The aim of this study is to estimate the prevalence of allergic rhinitis and its associated risk factors in vendors.

\section{Methods}

\subsection{Study Design and Population}

It was an analytical cross-sectional study in the neighborhoods of HLM (Habitats with low rent), Medina and Petersen, which include the largest markets in the city of Dakar (Senegal). The study took place in November and December 2016. These markets are located within 100 meters of roads that are heavily frequented by vehicles (Figure 1). Vendors who work near these high traffic roads have been invited to participate in this study. The size of the sample was calculated with the Schwartz formula adapted to cross-sectional studies [23]. The prevalence of allergic rhinitis among formal office workers in Dakar, which is $7.5 \%$, was used to calculate the sample size. With a confidence interval of $95 \%$ and a margin of error of $5 \%$, the smallest size to obtain a representative sample is

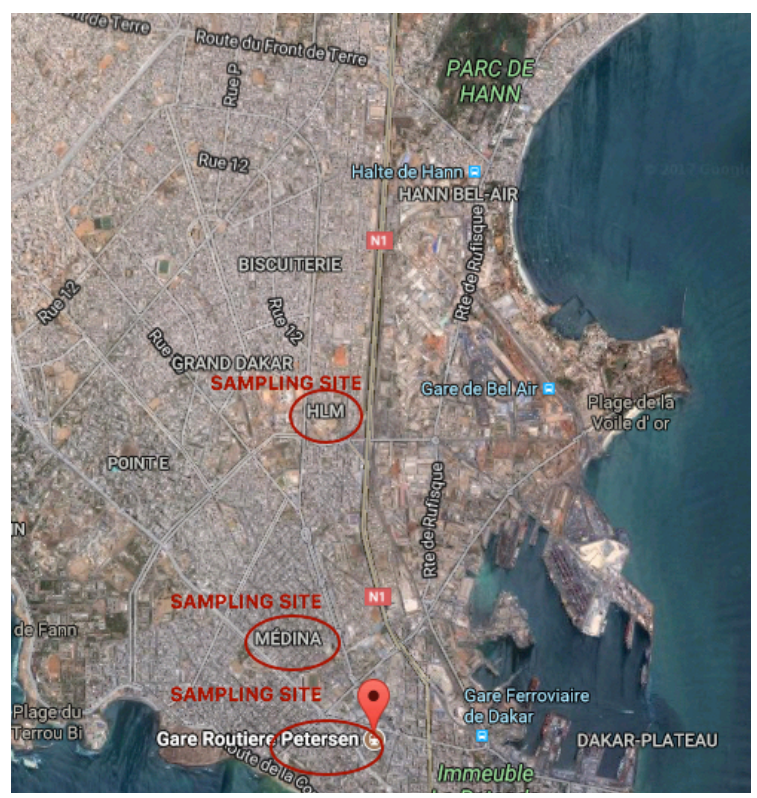

Figure 1. The location of the study areas in Dakar city. 
106 vendors. A proportion of $50 \%$ was added to the sample size to predict non-respondents. A final sample of 200 vendors was obtained.

\subsection{Selection of Study Participants}

Given the lack of registration of informal vendors in Dakar, a non-probabilistic sampling technique and was used to select vendors. Vendors in the HLM, Medina and Petersen markets located less than $50 \mathrm{~m}$ from high traffic roads were approached. Data were collected on weekdays except Sunday. As the markets in the different neighborhoods under study were about the same size, the 200 vendors were taken equally between the three study areas. Vendors who are at least 18 years old and have been in the trade for at least one year have been included in the study. Written and informed consent was requested from all participating vendors prior to their inclusion in the study.

\subsection{Interviews}

Three interviewers, who received complete training on the study and on the questionnaire, collected the data. Pre-tests of the questionnaire were carried out in the field outside the study areas before formal data collection began. The questionnaires were checked at the end of each daily collection by the investigators to check the data fill. Incomplete questionnaires were excluded from the data analysis. Data quality was assessed by random checks by the principal investigator.

The questionnaire included variables related to socio-economic characteristics, occupational factors and respiratory symptoms. A team of specialists in public health and pneumologists validated the questionnaire. The data collected was entered in the Epi Info software (version 7). A code has been assigned to participants to preserve the confidentiality of their data.

\subsection{Operational Definition of the Study Outcome}

Rhinitis was diagnosed in the presence of sneezing, rhinorrhea, nasal congestion, postnasal discharge and constant itching of the eyes and nose [24].

\subsection{Anthropometric Measures}

The anthropometric parameters measured are the weight $(\mathrm{kg})$ and the size $(\mathrm{m})$ using an electronic balance and a toise. The body mass index (BMI) was calculated by the weight $(\mathrm{kg}) / \mathrm{height}\left(\mathrm{m}^{2}\right)$ ratio. A BMI greater than $25 \mathrm{Kg} / \mathrm{m}^{2}$ was considered overweight.

\subsection{Ethical Approval}

Ethical approval was granted by the University of Cheikh Anta Diop Ethics and Research Committee, Dakar, Senegal. The code and date of ethical approval was Protocole 0090/2015/CER/UCAD, 08 January 2016. 


\subsection{Statistical Analysis}

A descriptive analysis was first conducted to describe the variables of the study. The qualitative variables were expressed in proportions. Quantitative variables were expressed as mean and standard deviation. A bivariate analysis was performed to determine the association between rhinitis as a dependent variable and independent variables such as personal characteristics, occupational factors (place of work, number of years in the trade, exposure time, etc.) as well as the presence of respiratory symptoms. The chi-square test was used for the crossing of the dependent variable and the qualitative explanatory variables. The crossing of the quantitative variables with the dependent variable was done with the Student test. Independent variables with $\mathrm{p}<0.25$ in the bivariate analysis were included in the multivariate analysis following the postulate of Hosmer and Lemeshow [25]. A logistic regression was performed to determine the adjusted and unadjusted relationship between rhinitis and independent variables. Effects of the independent variables were adjusted for smoking status and education level. Odds ratios with their confidence intervals were obtained of the different categories of independent variables. In all statistical tests, the confidence interval was $95 \%$ and $\mathrm{p}<0.05$ was considered statistically significant. Statistical analyzes were carried out with software R (version 3.3.3).

\section{Results}

The mean age of the vendors was 31.9 years ( $\mathrm{SD}=10.2$ years) and the majority of them had no education (58\%). Most of vendors (59\%) go to their workplaces by public transportation and $70 \%$ of vendors find that they are exposed to other types of pollution or road traffic. Vendors had an average of 8.9 years $(\mathrm{SD}=7.7$ years) of professional activity in the trade and worked on average 6.6 days (SD $=$ 0.6 days) per week. The average daily working time for these vendors was 11.6 hours (SD $=2.2$ hours). Smoking was found only in $4 \%$ of vendors (Table 1 ). Vendors reported respiratory symptoms such as recurrent cold, cough, wheezing at $84 \%, 30 \%$ and $10 \%$, respectively (Table 2 ). Symptoms of allergic rhinitis were predominantly found in vendors such as sneezing (40\%), nasal discharge (62\%), nasal congestion (72\%), and eye irritation (49\%). Headaches were reported at $70 \%$ and wheezing at $10 \%$ by vendors. Allergic rhinitis was found in $43 \%$ of vendors (Table 2). Table 3 shows the bivariate analysis with the reported prevalence of allergic rhinitis according to several factors. Age is significantly associated with rhinitis $(\mathrm{p}=0.02)$ with a higher prevalence in those less than 40 years. Vendors who are exposed to other types of pollution in addition to pollution from traffic have reported suffering more rhinitis with a significant association $(p=0.01)$. The working area and the number of hours worked per day are significantly associated with rhinitis with respective $\mathrm{p}$-values of $\mathrm{p}<0.001$ and $\mathrm{p}$ $=0.001$. Vendors who reported frequent respiratory symptoms such as cold, cough and sleep disorders had a high prevalence of allergic rhinitis with a significant association $(\mathrm{p}<0.05)$. BMI is associated with allergic rhinitis with a signif- 
Table 1. Socio-demographic characteristics of vendors in the neighborhoods of HLM, Medina and Petersen, Dakar, Senegal $(\mathrm{n}=200)$.

\begin{tabular}{|c|c|c|}
\hline Variables & & $\mathrm{n}(\%)$ \\
\hline \multicolumn{3}{|l|}{ Age (years) Mean (SD): 31.9 (10.2) } \\
\hline \multicolumn{2}{|l|}{ Less than 40 years } & $157(79)$ \\
\hline \multicolumn{2}{|l|}{40 years and above } & $43(21)$ \\
\hline \multicolumn{3}{|l|}{ Sex } \\
\hline \multicolumn{2}{|l|}{ Male } & $120(60)$ \\
\hline \multicolumn{2}{|l|}{ Female } & $80(40)$ \\
\hline \multicolumn{3}{|l|}{ Education status } \\
\hline \multicolumn{2}{|l|}{ None } & $116(58)$ \\
\hline \multicolumn{2}{|l|}{ Primary } & $36(18)$ \\
\hline \multicolumn{2}{|l|}{ Secondary and tertiary } & $48(24)$ \\
\hline \multicolumn{3}{|l|}{ Matrimonial status } \\
\hline \multicolumn{2}{|l|}{ Single } & $80(40)$ \\
\hline \multicolumn{2}{|l|}{ Married } & $111(56)$ \\
\hline \multicolumn{2}{|l|}{ Divorced } & $7(4)$ \\
\hline \multicolumn{3}{|l|}{ Family size Mean (SD): 1.5 (2.4) } \\
\hline \multicolumn{2}{|l|}{ Less than two children } & $121(63)$ \\
\hline \multicolumn{2}{|l|}{ Two or more children } & $72(37)$ \\
\hline \multicolumn{3}{|l|}{ Transportation } \\
\hline \multicolumn{2}{|l|}{ Particular vehicle } & $7(4)$ \\
\hline \multicolumn{2}{|l|}{ Public transport } & $118(59)$ \\
\hline \multicolumn{2}{|l|}{ Others } & $75(38)$ \\
\hline \multicolumn{3}{|l|}{ BMI $\left(\mathrm{Kg} / \mathrm{m}^{2}\right) \quad$ Mean (SD): $23.9(4.8)$} \\
\hline \multicolumn{2}{|l|}{ Less than 30} & $137(68)$ \\
\hline 30 and above & & $63(32)$ \\
\hline Current smoking & & \\
\hline Yes & & $7(4)$ \\
\hline No & & $193(96)$ \\
\hline Sales area & & \\
\hline HLM & & $66(33)$ \\
\hline Medina & & $68(34)$ \\
\hline Petersen & & $66(33)$ \\
\hline Exposure to other types of pollution & & \\
\hline Yes & & $141(70)$ \\
\hline No & & $59(30)$ \\
\hline Workplace & & \\
\hline Shop & & $109(54)$ \\
\hline Street & & $91(46)$ \\
\hline Duration of the work in the place (years) & Mean (SD): 5.1 (5.9) & \\
\hline Less than 5 years & & $138(69)$ \\
\hline 5 years and above & & $62(31)$ \\
\hline Duration on job (years) Mean (SD): 8.9( & (7.7) & \\
\hline Less than 9 years & & $160(80)$ \\
\hline 9 years and above & & $40(20)$ \\
\hline Number of working days per week (days) & Mean (SD): $6.6(0.6)$ & \\
\hline Less than 6 days & & $75(38)$ \\
\hline 6 days and above & & $125(62)$ \\
\hline Number of hours worked per day (hours) & Mean (SD):11.6 (2.2) & \\
\hline Less than 12 hours & & $97(48)$ \\
\hline 12 hours and above & & $103(52)$ \\
\hline
\end{tabular}

Values in parentheses are percentages. Abbreviations: BMI, Body mass index; HLM: Habitats with low rent. 
Table 2. Health status of vendors in the neighborhoods of HLM, Medina and Petersen, Dakar, Senegal $(\mathrm{n}=200)$.

\begin{tabular}{|c|c|}
\hline Variables & n (\%) \\
\hline \multicolumn{2}{|l|}{ Cold } \\
\hline Yes & $167(84)$ \\
\hline No & $33(16)$ \\
\hline \multicolumn{2}{|l|}{ Headaches } \\
\hline Yes & $139(70)$ \\
\hline No & $61(30)$ \\
\hline \multicolumn{2}{|l|}{ Cough } \\
\hline Yes & $60(30)$ \\
\hline No & $140(70)$ \\
\hline \multicolumn{2}{|c|}{ Family history of asthma } \\
\hline Yes & $68(34)$ \\
\hline No & $132(66)$ \\
\hline \multicolumn{2}{|c|}{ Have you had any wheezing in the past 12 months? } \\
\hline Yes & $19(10)$ \\
\hline No & $181(90)$ \\
\hline \multicolumn{2}{|c|}{ Do you have sleep disorders? } \\
\hline Yes & $58(29)$ \\
\hline No & $142(71)$ \\
\hline \multicolumn{2}{|c|}{ Do you have asthma attacks? } \\
\hline Yes & $13(6)$ \\
\hline No & $187(94)$ \\
\hline \multicolumn{2}{|c|}{ Do you have wheezing during or after exercise? } \\
\hline Yes & $21(10)$ \\
\hline No & $179(90)$ \\
\hline \multicolumn{2}{|c|}{ Do you have a series of sneezing during the past 12 months? } \\
\hline Yes & $81(40)$ \\
\hline No & $119(60)$ \\
\hline \multicolumn{2}{|c|}{ Do you have a runny nose? } \\
\hline Yes & $124(62)$ \\
\hline No & $76(38)$ \\
\hline \multicolumn{2}{|c|}{ Do you have a nasal congestion? } \\
\hline Yes & $144(72)$ \\
\hline No & $56(28)$ \\
\hline \multicolumn{2}{|c|}{ Do you have teary and itchy eyes? } \\
\hline Yes & $98(49)$ \\
\hline No & $102(51)$ \\
\hline \multicolumn{2}{|c|}{ Do you have a problem with the nose or discomfort? } \\
\hline Yes & $18(9)$ \\
\hline No & $182(91)$ \\
\hline \multicolumn{2}{|c|}{ Confirmed rhinitis } \\
\hline Yes & $81(40)$ \\
\hline No & $119(60)$ \\
\hline
\end{tabular}

Values in parentheses are percentages. 
Table 3. Distribution of self-reported allergic rhinitis by socio-demographic and occupational variables among vendors in the neighborhoods of HLM, Medina and Petersen, Dakar, Senegal $(\mathrm{n}=81)$.

\begin{tabular}{|c|c|c|}
\hline \multirow{2}{*}{ Variables } & \multicolumn{2}{|c|}{ Allergic rhinitis } \\
\hline & n (\%) & $\mathrm{p}$-value \\
\hline Age & & $0.02^{*}$ \\
\hline 40 years and above & $13(16)$ & \\
\hline Less than 40 years & $68(84)$ & \\
\hline Sex & & 0.08 \\
\hline Female & $55(68)$ & \\
\hline Male & $26(32)$ & \\
\hline Education status & & 0.97 \\
\hline None & $46(57)$ & \\
\hline Primary & $15(18)$ & \\
\hline Secondary and tertiary & $20(25)$ & \\
\hline Matrimonial status & & 0.54 \\
\hline Single & $35(44)$ & \\
\hline Married & $44(54)$ & \\
\hline Divorced & $2(2)$ & \\
\hline Number of children & & 0.06 \\
\hline Less than 3 children & $65(82)$ & \\
\hline 3 or more children & $14(18)$ & \\
\hline Exposure to other types of pollution & & $0.01^{*}$ \\
\hline No & $16(20)$ & \\
\hline Yes & $65(80)$ & \\
\hline Sales area & & $<0.001^{* * *}$ \\
\hline HLM & $20(25)$ & \\
\hline Medina & $44(54)$ & \\
\hline Petersen & $17(21)$ & \\
\hline Workplace & & 0.33 \\
\hline Street & $33(41)$ & \\
\hline Shop & $48(59)$ & \\
\hline Duration of the work in the place & & 0.66 \\
\hline Less than 5 years & $54(67)$ & \\
\hline 5 years and above & $27(33)$ & \\
\hline Duration on job & & 0.50 \\
\hline Less than 9 years & $42(52)$ & \\
\hline 9 years and above & $39(48)$ & \\
\hline Number of working days per week & & 0.57 \\
\hline Less than 6 days & $28(35)$ & \\
\hline 6 days and above & $53(65)$ & \\
\hline Number of hours worked per day & & $0.001^{\star *}$ \\
\hline Less than 12 hours & $28(35)$ & \\
\hline 12 hours and above & $53(65)$ & \\
\hline BMI & & $0.03^{*}$ \\
\hline $30 \mathrm{Kg} / \mathrm{m}^{2}$ and above & $4(5)$ & \\
\hline Less than $30 \mathrm{Kg} / \mathrm{m}^{2}$ & $76(95)$ & \\
\hline
\end{tabular}

${ }^{*} \mathrm{p}<0.05,{ }^{* *} \mathrm{p}<0.01,{ }^{* * *} \mathrm{p}<0.001$. Values in parentheses are percentages. Abbreviations: BMI, Body mass index; HLM: Habitats with low rent. 


\begin{tabular}{|c|c|c|}
\hline \multirow{2}{*}{ Variables } & \multicolumn{2}{|c|}{ Allergic rhinitis } \\
\hline & n (\%) & p-value \\
\hline Reported respiratory diseases related to the occupation & & $<0.001^{* * *}$ \\
\hline No & $62(76)$ & \\
\hline Yes & $19(24)$ & \\
\hline Frequency of the occurrence of respiratory diseases & & 0.18 \\
\hline Seldom & $25(31)$ & \\
\hline Often & $13(16)$ & \\
\hline Frequently & $43(53)$ & \\
\hline Cold & & $0.001^{\star *}$ \\
\hline No & $4(5)$ & \\
\hline Yes & $77(95)$ & \\
\hline Headaches & & 0.17 \\
\hline No & $26(32)$ & \\
\hline Yes & $55(68)$ & \\
\hline Cough & & $0.001^{* *}$ \\
\hline No & $46(57)$ & \\
\hline Yes & $35(43)$ & \\
\hline Family history of asthma & & 0.55 \\
\hline No & $51(63)$ & \\
\hline Yes & $30(37)$ & \\
\hline Wheezing & & 0.23 \\
\hline No & $69(85)$ & \\
\hline Yes & $12(15)$ & \\
\hline Sleep disorders & & $0.01^{\star}$ \\
\hline Never & $49(60)$ & \\
\hline Less than one night per week & $19(24)$ & \\
\hline One night or more per week & $13(16)$ & \\
\hline Asthma attack & & 0.05 \\
\hline No & $10(12)$ & \\
\hline Yes & $71(88)$ & \\
\hline Dyspnea of effort & & 0.10 \\
\hline No & $67(83)$ & \\
\hline Yes & $14(17)$ & \\
\hline Dry cough at night & & $<0.001^{\star * *}$ \\
\hline No & $50(62)$ & \\
\hline Yes & $31(38)$ & \\
\hline
\end{tabular}

${ }^{*} \mathrm{p}<0.05,{ }^{* *} \mathrm{p}<0.01,{ }^{* * *} \mathrm{p}<0.001$. Values in parentheses are percentages.

icant p-value of 0.03 . Gender, marital status, number of years in the trade and presence of wheezing were not significantly associated to allergic rhinitis $(\mathrm{p}>$ 0.05). Table 4 shows the logistic regression analysis of the association between the different variables (socio-occupational factors and symptoms) and allergic rhinitis. Age is a risk factor for allergic rhinitis. Vendors under the age of 40 have 3.28 times more risk of having allergic rhinitis than vendors over 40 years of age. Vendors exposed to several sources of pollution are 4 times more likely to have allergic rhinitis than vendors exposed to air pollution from road traffic [OR: $4.08(1.43-11.63)]$. The location of the working area is also a risk factor for 
Table 4. Regression analysis on relationship of independent variables with allergic rhinitis of vendors in the neighborhoods of HLM, Medina and Petersen, Dakar, Senegal $(\mathrm{n}=200)$.

\begin{tabular}{|c|c|c|c|}
\hline Variables & p-value & Crude OR $(95 \% \mathrm{CI})$ & Ajusted OR (95\%CI) \\
\hline \multicolumn{4}{|l|}{ Age } \\
\hline Less than 40 years & $0.046^{\star}$ & 1 & 1 \\
\hline 40 years and above & & $2.43(1.1-5.38)$ & $3.28(1.02-10.51)$ \\
\hline \multicolumn{4}{|l|}{ Sex } \\
\hline Male & 0.506 & 1 & 1 \\
\hline Female & & $0.63(0.34-1.17)$ & $1.42(0.51-3.96)$ \\
\hline \multicolumn{4}{|l|}{ Number of children } \\
\hline Less than 3 children & 0.562 & 1 & 1 \\
\hline 3 or more children & & $0.42(0.2-0.89)$ & $0.73(0.25-2.14)$ \\
\hline \multicolumn{4}{|c|}{ Exposure to others types of pollution } \\
\hline No & & 1 & 1 \\
\hline Yes & $0.008^{\star *}$ & $1.99(1-3.93)$ & $4.08(1.43-11.63)$ \\
\hline \multicolumn{4}{|l|}{ Sale areas } \\
\hline HLM & & 1 & 1 \\
\hline Medina & $0.001^{\star *}$ & $4.82(2.23-10.43)$ & $8.31(2.39-28.95)$ \\
\hline Petersen & 0.763 & $0.98(0.44-2.17)$ & $1.18(0.41-3.41)$ \\
\hline \multicolumn{4}{|c|}{ Number of hours worked per day } \\
\hline Less than 12 hours & & 1 & 1 \\
\hline 12 hours and above & 0.135 & $2.38(1.29-4.38)$ & $2.05(0.8-5.25)$ \\
\hline \multicolumn{4}{|c|}{ Reported respiratory diseases related to the occupation } \\
\hline No & & 1 & 1 \\
\hline Yes & $0.031^{*}$ & $4.71(1.76-12.6)$ & $4.39(1.15-16.85)$ \\
\hline \multicolumn{4}{|l|}{ Cold } \\
\hline No & & 1 & 1 \\
\hline Yes & $0.029^{*}$ & $7.56(1.69-33.83)$ & $14.68(1.32-163.23)$ \\
\hline \multicolumn{4}{|l|}{ Headaches } \\
\hline No & & 1 & 1 \\
\hline Yes & 0.177 & $2.07(0.4-10.65)$ & $0.5(0.18-1.36)$ \\
\hline \multicolumn{4}{|l|}{ Cough } \\
\hline No & & 1 & 1 \\
\hline Yes & $0.013^{*}$ & $0.48(0.13-1.84)$ & $3.23(1.28-8.15)$ \\
\hline \multicolumn{4}{|c|}{ Frequency of the occurrence of respiratory diseases } \\
\hline Seldom & & 1 & 1 \\
\hline Often & $0.009^{* *}$ & $1.24(0.41-3.7)$ & $6.58(1.6-26.98)$ \\
\hline Frequently & $0.008^{\star *}$ & $1.95(0.74-5.18)$ & $4.66(1.48-14.64)$ \\
\hline \multicolumn{4}{|l|}{ BMI } \\
\hline Less than $30 \mathrm{Kg} / \mathrm{m}^{2}$ & & 1 & 1 \\
\hline $30 \mathrm{Kg} / \mathrm{m}^{2}$ or more & 0.40 & $0(0-$ Inf $)$ & $0.52(0.11-2.44)$ \\
\hline
\end{tabular}

${ }^{*} \mathrm{p}<0.05,{ }^{* *} \mathrm{p}<0.01,{ }^{* * *} \mathrm{p}<0.001$. Abbreviations: BMI, Body mass index; HLM: Habitats with low rent. 
allergic rhinitis. Thus vendors located in the neighborhood of Medina are 8 times more likely to have allergic rhinitis than those located at the HLM [OR: 8.31 (2.39 - 28.95)]. Vendors reporting respiratory symptoms such as cold and cough were 14 times [OR: $14.68(1.32$ - 163.23)] and three times more likely [OR: $3.23(1.28-8.15)]$ to have allergic rhinitis than vendors without respiratory symptoms.

\section{Discussion}

The study aimed to determine the prevalence of allergic rhinitis and its associated risk factors in vendors who are highly exposed to air pollution from road traffic in Dakar city. The prevalence of allergic rhinitis found was $43 \%$ among vendors. The prevalence of allergic rhinitis reported in this study is close to that reported (43.6\%) in adults who are highly exposed to air pollution from road traffic in Sweden [17]. The prevalence of allergic rhinitis in this study is high compared to that reported in Bogota (26.1\%) in traffic police [26] and in a study done in Benin [27] among residents near busy roads with a prevalence of allergic rhinitis of $35.7 \%$. Studies have shown higher prevalence of allergic rhinitis than those found in our study in workers with high exposure to outdoor air pollution in Nigeria (48.9\%) [28] and Italy (48.5\%) [29]. Consistent with previous studies, the prevalence of allergic rhinitis decreases with age [6] [30]. Similarly, prevalence among men and women does not differ [6]. The working area of the vendors is a risk factor for allergic rhinitis. Vendors located in the neighborhood of Medina had a higher prevalence of allergic rhinitis. The neighborhood of Medina includes several sources of pollution other than air pollution from road traffic. Vendors have reported other types of pollution sources such as the lack of an adequate sanitation system with the opening of septic tanks, bad odors and the presence of household waste. The road traffic in Medina is very dense because it includes the main avenues of Dakar city, and the market of Medina is very narrow and crowded. Air pollution has been shown to be one of the major environmental risk factors for allergic rhinitis [31]. A workplace near a high traffic road is also associated with allergic rhinitis [27] as found in our study. The fine particles, mostly derived from road traffic, are ultrafine size $(<100 \mathrm{~nm})$ and can be deposited in the nasal and peripheric airways. These fine particles induce oxidative stress and hyper-reactivity of the respiratory tract by increasing inflammation of the respiratory tract and allergic responses such as allergic rhinitis [15]. Vendors who had a long daily working time, had a higher prevalence of allergic rhinitis. This is due to the duration of exposure to air pollutants as shown by the study by Obaseki et al., 2014 [28]. Some studies showed that BMI is associated with the prevalence of allergic rhinitis. Our results are similar to the findings of these studies where people with allergic rhinitis have a higher BMI than those who did not suffer from allergic rhinitis [32] [33]. Overweight could have a role in the development of rhinitis [33]. Our results showed that the presence of chronic cough and recurrent cold were risk factors of allergic rhinitis. It 
should also be noted that chronic cough and recurrent cold may be clinical manifestations of allergic rhinitis. Thus, allergic rhinitis has been shown to be an independent risk factor for chronic cough and that different processes may be involved in the association of allergic rhinitis with chronic cough [34]. Vendors who reported frequent respiratory symptoms and diseases had a higher prevalence of allergic rhinitis. Allergic rhinitis is characterized by a recurrence of respiratory symptoms [4], hence the greatest number of complaints of the frequency of occurrence of these respiratory symptoms in vendors suffering from allergic rhinitis.

\section{Limitations of the study}

Firstly, the design of this study is a cross-sectional study. The prevalence of allergic rhinitis found in this study may be higher than the actual prevalence since our results are based on the self-reported answers from the questionnaire. Secondly, the presence of indoor air pollution at the vendor's household was not assessed in the questionnaire. It is known that indoor air pollution plays a role in the onset and exacerbation of allergic rhinitis. Thirdly, the level of exposure to air pollution has not been quantified by measuring devices in these vendors. However, the results are similar to the results of other studies, suggesting that air pollution from cars plays a role in the exacerbation or onset of allergic rhinitis. Lastly, the study was conducted from November to December 2017, in Senegal July to September fall in the dry season, while November to June falls humid season. It is possible, when data were collected during dry months with higher concentrations of pollutants, that vendors might have reported more respiratory symptoms.

\section{Conclusion}

This study found a high prevalence of allergic rhinitis among vendors in Dakar city. An association between factors related to occupation and allergic rhinitis was found among these vendors. Factors associated with the presence of allergic rhinitis in these vendors were the age, the working area with dense road traffic, the exposure to multiple sources of pollution and the presence and frequency of respiratory symptoms such as cold and cough. With the rapid and continuous urbanization process, more and more people are exposed to high levels of air pollution. Environmental control and public health strategies should be strengthened by health decision-makers to address this worrying problem. Vendors, who are highly exposed to air pollution from cars, should be sensitized and treated appropriately.

\section{Conflict of Interest}

The authors declare that they have no conflicts of interest in relation to this article. 


\section{Acknowledgements}

We thank the International Development Research Centre (IRDC) for the financial support to this work. We would like also to thank the vendors for their time and valuable information that they provided for this study.

\section{References}

[1] Ozdoganoglu, T. and M.S. (2012) The Burden of Allergic Rhinitis and Asthma. Therapeutic Advances in Respiratory Disease, 6, 11-23. https://doi.org/10.1177/1753465811431975

[2] Greiner, A.N. and Meltzer, E.O. (2011) Overview of the Treatment of Allergic Rhinitis and Nonallergic Rhinopathy. Proceedings of the American Thoracic Society, $\mathbf{8}$, 121-131. https://doi.org/10.1513/pats.201004-033RN

[3] Izquierdo-Dominguez, A., Valero, A.L. and Mullol, J. (2013) Comparative Analysis of Allergic Rhinitis in Children and Adults. Current Allergy and Asthma Reports, 13, 142-151. https://doi.org/10.1007/s11882-012-0331-y

[4] Deng, Q., et al. (2016) Early Life Exposure to Traffic-Related Air Pollution and Allergic Rhinitis in Preschool Children. Respiratory Medicine, 121, 67-73.

https://doi.org/10.1016/j.rmed.2016.10.016

[5] Greiner, A.N., et al. (2011) Allergic Rhinitis. Lancet, 378, 2112-2122. https://doi.org/10.1016/S0140-6736(11)60130-X

[6] Skoner, D.P. (2001) Allergic Rhinitis: Definition, Epidemiology, Pathophysiology, Detection, and Diagnosis. Journal of Allergy and Clinical Immunology, 108, S2-S8. https://doi.org/10.1067/mai.2001.115569

[7] Schoenwetter, W.F., et al. (2004) Economic Impact and Quality-of-Life Burden of Allergic Rhinitis. Current Medical Research and Opinion, 20, 305-317. https://doi.org/10.1185/030079903125003053

[8] Mandhane, S.N., Shah, J.H. and Thennati, R. (2011) Allergic Rhinitis: An Update on Disease, Present Treatments and Future Prospects. International Immunopharmacology, 11, 1646-1662. https://doi.org/10.1016/j.intimp.2011.07.005

[9] Soto-Quiros, M.E., et al. (2002) Maternal History, Sensitization to Allergens, and Current Wheezing, Rhinitis, and Eczema among Children in Costa Rica. Pediatric Pulmonology, 33, 237-243. https://doi.org/10.1002/ppul.10070

[10] Worldwide Variation in Prevalence of Symptoms of Asthma, Allergic Rhinoconjunctivitis, and Atopic Eczema: ISAAC (1998) The International Study of Asthma and Allergies in Childhood (ISAAC) Steering Committee. Lancet, 351, 1225-1232.

[11] Kim, H.H., et al. (2013) Analysis of the Association between Air Pollution and Allergic Diseases Exposure from Nearby Sources of Ambient Air Pollution within Elementary School Zones in Four Korean Cities. Environmental Science and Pollution Research, 20, 4831-4846. https://doi.org/10.1007/s11356-012-1358-2

[12] Penard-Morand, C., et al. (2005) Long-Term Exposure to Background Air Pollution Related to Respiratory and Allergic Health in Schoolchildren. Clinical and Experimental Allergy, 35, 1279-1287. https://doi.org/10.1111/j.1365-2222.2005.02336.x

[13] Acciani, T.H., et al. (2013) Diesel Exhaust Particle Exposure Increases Severity of Allergic Asthma in Young Mice. Clinical and Experimental Allergy, 43, 1406-1418. https://doi.org/10.1111/cea.12200

[14] Brandt, E.B., et al. (2013) Diesel Exhaust Particle Induction of IL-17A Contributes to Severe Asthma. Journal of Allergy and Clinical Immunology, 132, 1194-1204. 
https://doi.org/10.1016/j.jaci.2013.06.048

[15] Takahashi, G., et al. (2010) Effect of Diesel Exhaust Particles on House Dust Mite-Induced Airway Eosinophilic Inflammation and Remodeling in Mice. Journal of Pharmacological Sciences, 112, 192-202. https://doi.org/10.1254/jphs.09276FP

[16] Kim, B.J., et al. (2011) Association of Ozone Exposure with Asthma, Allergic Rhinitis, and Allergic Sensitization. Annals of Allergy, Asthma \& Immunology, 107, 214-219. https://doi.org/10.1016/j.anai.2011.05.025

[17] Lindgren, A., et al. (2009) Traffic Exposure Associated with Allergic Asthma and Allergic Rhinitis in Adults. A Cross-Sectional Study in Southern Sweden. International Journal of Health Geographics, 8, 25. https://doi.org/10.1186/1476-072X-8-25

[18] Ndiaye, M., et al. (2004) Application of the WHO Program on "Chronic Respiratory Diseases" in Sub-Saharan Africa: Problem in Senegal. Review of Respiratory Diseases, 21, 479-491. https://doi.org/10.1016/S0761-8425(04)71352-2

[19] Grammer 3rd, L.C. (2016) Occupational Rhinitis. Immunology and Allergy Clinics of North America, 36, 333-341. https://doi.org/10.1016/j.iac.2015.12.009

[20] Alfers, L. and Rogan, M. (2015) Health Risks and Informal Employment in South Africa: Does Formality Protect Health? International Journal of Occupational and Environmental Health, 21, 207-215. https://doi.org/10.1179/2049396714Y.0000000066

[21] Abegunde, D.O., et al. (2007) The Burden and Costs of Chronic Diseases in Low-Income and Middle-Income Countries. Lancet, 370, 1929-1938. https://doi.org/10.1016/S0140-6736(07)61696-1

[22] Ndiaye, M., et al. (2011) Prevalence and Clinical Phenotype of the Respiratory Allergies in Workplaces to Dakar, Senegal. Revue Française d'Allergologie, 51, 529-600. https://doi.org/10.1016/j.reval.2011.01.014

[23] Hsieh, F.Y., Bloch, D.A. and Larsen, M.D. (1998) A Simple Method of Sample Size Calculation for Linear and Logistic Regression. Statistics in Medicine, 17, 1623-1634. https://doi.org/10.1002/(SICI)1097-0258(19980730)17:14<1623::AID-SIM871>3.0.C $\underline{\mathrm{O} ; 2-\mathrm{S}}$

[24] Brisman, J., Jarvholm, B. and Lillienberg, L. (2000) Exposure-Response Relations for Self Reported Asthma and Rhinitis in Bakers. Occupational and Environmental Medicine, 57, 335-340. https://doi.org/10.1136/oem.57.5.335

[25] Hosmer, D.W., Taber, S. and Lemeshow, S. (1991) The Importance of Assessing the Fit of Logistic Regression Models: A Case Study. American Journal of Public Health, 81, 1630-1635. https://doi.org/10.2105/AJPH.81.12.1630

[26] Estevez-Garcia, J.A., Rojas-Roa, N.Y. and Rodriguez-Pulido, A.I. (2013) Occupational Exposure to Air Pollutants: Particulate Matter and Respiratory Symptoms Affecting Traffic-Police in Bogota. Revista de Salud Pública (Bogota), 15, 889-902.

[27] Flatin, M.C., et al. (2017) Symptoms of Allergic Rhinitis in Parakou, Benin: Prevalence, Severity and Associated Factors. European Annals of Otorhinolaryngology, Head and Neck Diseases.

[28] Obaseki, D.O., et al. (2014) Respiratory Symptom, Lung Function and Exhaled Carbon Monoxide among a Sample of Traffic Workers in Lagos, Nigeria: A Pilot Survey. Nigerian Medical Journal, 55, 306-309. https://doi.org/10.4103/0300-1652.137190

[29] Vimercati, L., et al. (2016) Respiratory Health in Waste Collection and Disposal Workers. International Journal of Environmental Research and Public Health, 13, 
631. https://doi.org/10.3390/ijerph13070631

[30] An, S.Y., et al. (2015) Analysis of Various Risk Factors Predisposing Subjects to Allergic Rhinitis. Asian Pacific Journal of Allergy and Immunology, 33, 143-151. https://doi.org/10.12932/AP0554.33.2.2015

[31] Dunlop, J., Matsui, E. and Sharma, H.P. (2016) Allergic Rhinitis: Environmental Determinants. Immunology and Allergy Clinics of North America, 36, 367-377. https://doi.org/10.1016/j.iac.2015.12.012

[32] Ciprandi, G., et al. (2013) Increased Body Mass Index and Bronchial Impairment in Allergic Rhinitis. The American Journal of Rhinology \& Allergy, 27, e195-e201. https://doi.org/10.2500/ajra.2013.27.3979

[33] Konno, S., et al. (2012) The Prevalence of Rhinitis and Its Association with Smoking and Obesity in a Nationwide Survey of Japanese Adults. Allergy, 67, 653-660. https://doi.org/10.1111/j.1398-9995.2012.02793.x

[34] Sherrill, D.L., et al. (2005) The Relation of Rhinitis to Recurrent Cough and Wheezing: A Longitudinal Study. Respiratory Medicine, 99, 1377-1385. https://doi.org/10.1016/j.rmed.2005.03.025 